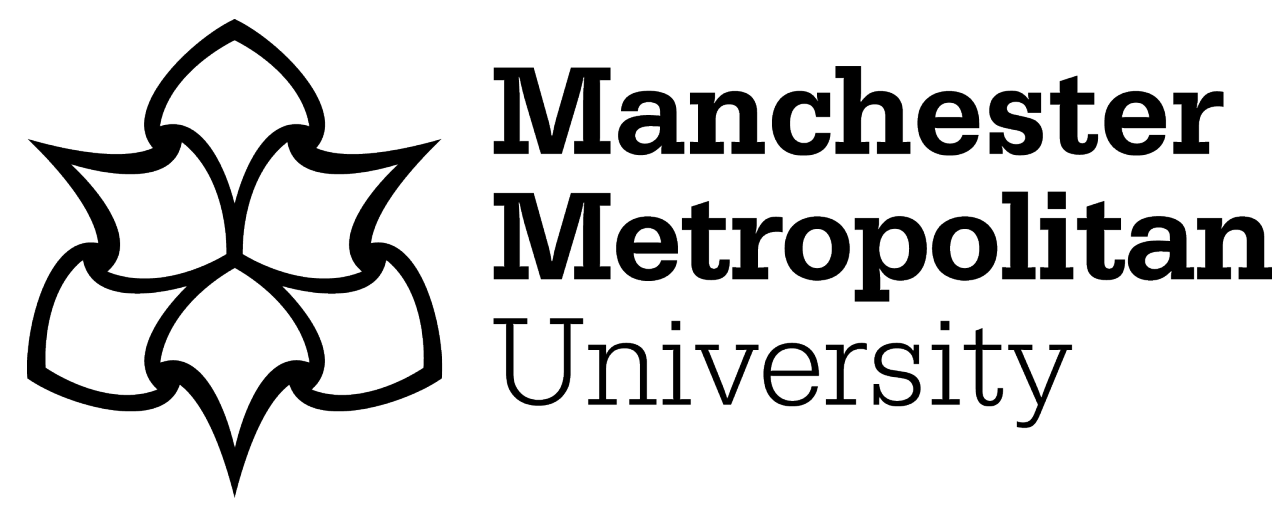

Dao, PHUNG, Nguyen, MAl and NGUYEN, Ngoc Bao Chau (2020) Effect of pronunciation instruction on L2 learners' listening comprehension. Journal of Second Language Pronunciation, 7 (1). pp. 10-37. ISSN 2215-1931

Downloaded from: https://e-space.mmu.ac.uk/625550/

Version: Accepted Version

Publisher: John Benjamins Publishing Company

DOI: https://doi.org/10.1075/jslp.19012.dao

Please cite the published version 
Dao, P., Nguyen, M. \& Nguyen, C. (2020, in press). Effect of pronunciation instruction on L2

learners' listening comprehension. Journal of Second Language Pronunciation.

\title{
Effect of pronunciation instruction on L2 learners' listening comprehension
}

Phung Dao (Author 1)

Manchester Metropolitan University, UK

Mai Xuan Nhat Chi Nguyen (Author 2)

Manchester Metropolitan University, UK

Ngoc Bao Chau Nguyen (Author 3)

Hue University of Foreign Languages, Vietnam

\section{To cite this article:}

Dao, P., Nguyen, M. \& Nguyen, C. (2020, in press). Effect of pronunciation instruction on L2 1 learners' listening comprehension. Journal of Second Language Pronunciation. Published online.

\begin{abstract}
This study explored the potential impact of pronunciation instruction on L2 listening comprehension. Seventy-two intermediate Vietnamese EFL university learners formed two groups. The pronunciation group $(\mathrm{n}=35)$ received seven weekly 45 -minute pronunciation instruction sessions targeting segmental and suprasegmental features of English. The control group $(\mathrm{n}=37)$ did not receive any pronunciation instruction. Weekly reflections, an exit questionnaire and focus group interviews were used to investigate learners' perceptions of the impact of the pronunciation instruction. Results showed that the two groups' immediate listening post-test scores did not differ significantly after the first two sessions on syllables and consonants/vowels. However, the pronunciation group outperformed the control group after three further pronunciation sessions on word stress, thought groups and sentence focus, but these differences disappeared on subsequent
\end{abstract}


Dao, P., Nguyen, M. \& Nguyen, C. (2020, in press). Effect of pronunciation instruction on L2 learners' listening comprehension. Journal of Second Language Pronunciation.

immediate and delayed post-tests. Self-report data indicated learners' positive perceptions of the helpfulness of the pronunciation instruction and how the gained pronunciation knowledge helped improve their listening comprehension.

Key words: pronunciation instruction, listening comprehension, phonological knowledge 
learners’ listening comprehension. Journal of Second Language Pronunciation.

\section{Effect of pronunciation instruction on L2 learners' listening comprehension}

\section{Introduction}

Previous research on second language (L2) pronunciation and listening comprehension has often investigated learners' development of these skills independently. Specifically, a large body of research has concentrated on examining learners' difficulties in listening comprehension (Graham, 2006; Goh, 2000; Hasan, 2000; Renandya \& Farrell, 2011) and the impact of strategies instruction on L2 learners' listening comprehension (Goh \& Taib, 2006; Graham \& Macaro, 2008; Ngo, 2015; Vandergrift \& Baker, 2015). Meanwhile, pronunciation instruction research has largely aimed to uncover the effect of pronunciation teaching on learners' L2 performance, with attention mainly paid to speaking production (Derwing, Munro, Foote, Waugh, \& Fleming, 2014; Kissling, 2013). These studies, however, have not adequately addressed the relationship between listening comprehension and pronunciation, despite suggestive speculations that L2 learners' listening comprehension might be influenced by whether they can perceive and produce sounds and rhythm in the target language (Brown, 2011; Gilbert, 2012; Flege, 1995; Kissling, 2018). In addition, research on L2 learners' difficulties in listening comprehension has revealed that they often encounter pronunciation-related issues that might have impacted on their listening comprehension (e.g. inability to decode in the stream of speech, failure to recognize known words in rapid spoken discourse, see Graham, 2006; Goh, 2000; Hasan, 2000; Renandya \& Farrell, 2011). Therefore, the current quasi-experimental pre-test/post-test study bridges this gap by investigating whether pronunciation instruction affects L2 learners' listening comprehension. Findings of this study will shed light on the potential impact of explicit pronunciation teaching on L2 listening comprehension 
Dao, P., Nguyen, M. \& Nguyen, C. (2020, in press). Effect of pronunciation instruction on L2

learners’ listening comprehension. Journal of Second Language Pronunciation.

and suggest pedagogical implications for incorporating pronunciation components into listening comprehension lessons.

\section{Literature review}

\subsection{Listening comprehension in L2 learning}

Listening comprehension is a difficult skill for L2 learners (Brown, 2011; Field, 2009). One of the main reasons is that there are multiple processes involved in listening comprehension. Brown and Lee (2015) summarize seven main processes of listening comprehension, including i) decoding sounds, ii) identifying the function of the speech event, iii) activating schemata or prior knowledge to understand what is said, iv) assigning literal meanings, v) assigning intended meanings, vi) specifying the demands for short or long-term memory, and vii) retaining meaning/information. To successfully navigate these processes, L2 listeners need to activate the ability to process spoken discourse from both a bottom-up and a top-down approach (Morley, 1991; Brown \& Lee, 2015). The former focuses on processing pieces of language such as sounds, words, grammatical relationships and lexical meanings, while the latter is concerned with activation of prior knowledge and emphasizes a global understanding of speech. In addition, a wide range of cognitive, metacognitive, as well as social strategies (see Vandergrift \& Goh, 2012) have been suggested to be crucial for effective listening comprehension, which makes listening comprehension in a second language even more challenging to learners.

\subsection{The relationship between listening comprehension and pronunciation}

Research has reported on various difficulties encountered by L2 learners in listening comprehension, ranging from vocabulary knowledge, memory, attention, speed of delivery, and a lack of proper listening comprehension strategies (see Brown, 2011 for a summary of studies). 
learners' listening comprehension. Journal of Second Language Pronunciation.

Among these research studies, one of the most commonly cited problems is learners' limited abilities to perceive the sounds and rhythm of the second language when used in (most often) authentic spoken discourse, which negatively impacts on their listening comprehension. These include failure to recognize known words used in natural speech and inability to break language into proper chunks (or limited speech segmentation skills) to facilitate understanding (Graham, 2006; Goh, 2000), or problems with the speed of delivery (Graham, 2006; Hasan, 2000; Renandya \& Farrell, 2011). It appears that these difficulties are connected to learners' pronunciation skills, which refer to their command, including both perception and production skills, of segmental (e.g. individual sounds) and suprasegmental (e.g. stress, rhythm, and intonation) features of the L2.

In recent years, it has been argued that listening comprehension and pronunciation are related. First, pronunciation skills may account for an important part of the bottom-up listening comprehension processes, in which learners utilize their phonological competence to decode the speech stream (Brown, 2011; Brown \& Lee, 2015). Phonological processes such as assimilation (neighbouring sounds affecting each other), elision (sounds getting dropped), and reduction (sounds being reduced in rapid speech), could therefore be fundamental in enhancing listening comprehension. In addition, from a communicative perspective, how learners hear a second language has been suggested to be closely linked with how they speak it (Gilbert, 2012). Thus, it is likely that awareness and practice of phonological features of the target language could help enhance both learners' speaking abilities and their listening comprehension. However, to date little empirical research evidence has confirmed whether L2 learners' pronunciation skills affect their listening comprehension. This warrants further research into this area to shed light on the relationship between pronunciation and listening comprehension.

\subsection{Teaching of listening comprehension and pronunciation skills}


learners' listening comprehension. Journal of Second Language Pronunciation.

The past few decades have witnessed a proliferation of research on listening comprehension and pronunciation instruction. Much research on the teaching of L2 listening comprehension has focused on the effect of learning strategies on enhancing listening comprehension (Goh \& Taib, 2006; Graham \& Macaro, 2008; Ngo, 2015; Vandergrift \& Baker, 2015; Yeldham \& Gruba, 2014). Notably, the listening comprehension strategies that were taught to learners in these existing studies were mostly top-down strategies such as predicting text content and vocabulary, listening for main ideas or for details, or making inferences while listening. While these techniques are essential to successful listening comprehension (Takeuchi, 2003), learners may also need practice with bottomup processes (e.g. sound system and rhythm) in order to effectively decode spoken text (Field, 2009). Given that recent research on pronunciation instruction has yielded positive results regarding the effect of teaching pronunciation on learners' speaking production (Derwing et al., 2014; Kissling, 2013) and the lack of experimental L2 research that investigates the relationship between pronunciation and listening comprehension, it is worthwhile to investigate the effectiveness of explicit pronunciation teaching on L2 learners' listening comprehension.

Kissling (2018) is one of the few studies that has examined whether pronunciation instruction impacted L2 learners' bottom-up listening comprehension, including speech segmentation and word recognition. Elementary L2 Spanish learners were assigned into groups and given pronunciation sessions on either segmental or suprasegmental aspects of Spanish, followed by either production- or perception-oriented practice. The results showed that pronunciation instruction coupled with perception- or production-focused practice helped learners perceive target language speech more intelligibly or comprehensibly, respectively. These findings suggest that there are benefits of pronunciation instruction for developing bottom-up listening comprehension. To tease apart the effect of pronunciation instruction on bottom-up listening comprehension, Kissling's study 
learners' listening comprehension. Journal of Second Language Pronunciation.

separated the instruction on segmental or suprasegmental aspects of pronunciation, and the followup practice was also divided as either perception- or production-based activity. However, one could argue that during the natural everyday listening process, L2 learners would most likely attend to both segmental and suprasegmental aspects to comprehend the spoken message (Gilbert, 2019). This suggests that pronunciation instruction needs to target both features. In addition, although different kinds of practice following pronunciation instruction have differential effects, it is possible that the combination of follow-up perception and production activities could result in greater positive impact on learners' listening comprehension. Additionally, Kissling (2018) assessed learners' listening comprehension using dictation tasks tailored specifically to evaluate bottom-up processing abilities, which was relevant for her study but arguably does not reflect authentic listening situations requiring global listening skills that learners encounter in real life. To address these issues, research that integrates pronunciation instruction on both segmental and suprasegment aspects, combines both perception and production follow-up practice in listening comprehension, and utilizes more comprehensive listening comprehension tests is needed.

The current study, therefore, investigates whether pronunciation instruction on specific aspects of English affects learners' listening comprehension and how the learners perceive the impact of the gained pronunciation knowledge on their listening comprehension. The study addresses two research questions.

1. Does pronunciation instruction on segmental and suprasegmental aspects affect L2 learners' listening comprehension?

2. What are learners' perceptions of the impact of this pronunciation instruction on their listening comprehension?

\section{Method}


Dao, P., Nguyen, M. \& Nguyen, C. (2020, in press). Effect of pronunciation instruction on L2

learners’ listening comprehension. Journal of Second Language Pronunciation.

\subsection{Participants}

Participants were 72 Vietnamese EFL learners (61 females) recruited from two classes in an intensive English program at a public university in Central Vietnam. Their age ranged from 19 to 22, with a mean of $19.17(S D=.50)$. Their English proficiency was assessed using a full TOEFL ITP test provided by Educational Testing Service (ETS), which included all three sections: Listening, Structure and Reading. The participants' TOEFL ITP test mean score prior to the pronunciation instruction was $416.56(S D=46.01)$, equivalent to Level A2 on the Common European Framework of Reference (CEFR). The two classes were randomly assigned into the pronunciation group $(n=35)$ and the control group $(n=37)$. The average TOEFL ITP test scores of the pronunciation group $(M=$ 412.51, $S D=28.49)$ and the treatment group $(M=420.37 ; S D=58.11)$ were not significantly different prior to the treatment, $t(70)=.723, p=.47, d=.17$. The two groups also reported that they had not received any explicit pronunciation instruction before participating in the study. To check that there were no differences in their listening comprehension due to the differences in phonological knowledge before the treatment, their TOEFL ITP listening comprehension pre-test scores between the pronunciation group $(M=41.76, S D=5.76)$ and control group $(M=40.54, S D=$ 4.06) were compared. The results showed that they were comparable groups, $t(70)=1.03, p=.310$, $d=.240$. The learners in both groups shared similar language learning backgrounds and reported having learned English for an average of 9.34 years $(S D=1.65)$; a few participants (5 learners) had learned another foreign language such as Chinese, French and Japanese. None of the participants reported visiting or studying in an English-speaking country.

At the time of data collection, the two groups were enrolled in a Listening course that aimed to develop first-year undergraduate English major students' listening comprehension. The course was structured into thematic units using the textbook Northstar: Listening and speaking Level 1 
learners’ listening comprehension. Journal of Second Language Pronunciation.

(Merdinger \& Barton, 2009). The classroom activities mainly included listening tasks taken from this textbook. The learners met for a 100-minute class scheduled weekly over a three-month semester. Course assessments were two individual listening tasks administered as midterm and final exams. Both groups used the same learning materials and were taught by a Vietnamese teacher of English who had seven years of teaching experience and a Master's degree in Applied Linguistics.

\subsection{Study design}

This study used a pre-test/post-test design to investigate the impact of pronunciation instruction on L2 learners' listening comprehension. The independent variable was the explicit pronunciation instruction on segmental and suprasegmental aspects of English and the dependent variable was learner's listening comprehension as measured by TOEFL ITP listening comprehension tests (see the test description below). The pronunciation group received seven pronunciation instruction sessions over a three-month period during a 15 -week semester and did a TOEFL ITP listening comprehension pre-test, three immediate post-tests after three sections of pronunciation instruction, and a delayed post-test. The control group was given the same TOEFL ITP listening comprehension tests but did not receive any pronunciation instruction. To further explore the impact of knowledge gained from the pronunciation instruction on listening comprehension, weekly reflections and focus group interviews were used.

\subsection{Pronunciation instruction sessions}

The pronunciation instruction (seven sessions in total) on phonological features of English was designed following Celce-Murcia, Brinton, Goodwin and Griner's (2010) pedagogical framework for teaching pronunciation, which includes five stages (collapsed into four stages for this study). The first stage (Description and analysis) was to present a phonological feature and show when and how it occurs. In this stage, the teacher introduced the phonological feature of the session 
learners' listening comprehension. Journal of Second Language Pronunciation.

by playing a recording that contained the target feature and directed learners' attention to it. The instructor also gave explanations of the phonological rules. The second stage (Listening discrimination) focused learner attention on individual phonological features. In this stage, the teacher used listening activities to direct learner attention to individual phonological features. Specifically, the learners listened to the target feature and were then asked to locate or differentiate it from other similar features. In the third stage (Controlled practice), the learners practiced the target features with learner attention focused completely on form. Activities included reading aloud (poems, rhymes, dialogues), tongue twisters, and contextualized minimal pairs. In the final stage (Guided and communicative practice), the learners carried out activities that focused their attention on meaning, grammar, and communicative intent as well as the target phonological feature. Activities included role plays, debates, drama scenes, and interviews. Most pronunciation activities used across the sessions were taken or adapted from Celce-Murcia et al. (2010) and Gilbert's (2012) Clear Speech (see Appendix for a sample of a pronunciation session plan). As can be seen, the second, third and fourth stages of this pronunciation instruction incorporated both perception- and production-oriented activities (see Kissling, 2018). Each pronunciation instruction session lasted for 45 minutes within a 100-minute regularly scheduled lesson.

\subsection{Target phonological features}

Seven phonological features targeted in the pronunciation sessions included segmentals and suprasegmentals (e.g., syllables, vowels/consonants, word stress, thought groups, sentence focus, intonation, and connected speech). These target phonological features were selected based on both practical and theoretical grounds. Concerning practical reasons, these target features comprised both segmental and suprasegmental aspects of the English language that the participants previously reported having difficulties with in an informally administered pre-course needs analysis survey. 
learners’ listening comprehension. Journal of Second Language Pronunciation.

Given time constraints, only seven topics were chosen to fit into the timetable of the participants' regularly scheduled classes. Theoretically speaking, the selected phonological targets took into account aspects of English pronunciation that have been shown to affect comprehension and intelligibility of L2 learners (Derwing et al., 2013).

\subsection{Materials}

The materials consisted of two full TOEFL ITP tests provided by Educational Testing Service (ETS). The full versions of the two TOEFL ITP tests consisting of three sections (i.e., Listening, Structure, and Reading) were delivered to the participants in order to assess their overall English proficiency. However, only the listening comprehension sections of the two tests were used as pre- and delayed post-tests and analysed in this study. The TOEFL ITP listening comprehension section was comprised of three parts with a total of 50 questions. The first part contained 30 questions assessing comprehension of short conversations. The second part ( 8 items) and the third part (12 items) gauged the learners' comprehension of long talks and several short talks, respectively. The test papers were returned to ETS for scoring, and the results were subsequently sent to the researchers (see ETS Score Overview of TOEF ITP, 2019). Three TOEFL ITP-type listening comprehension tests (short versions) were also used as immediate post-tests, each of which consisted of 10 listening comprehension items and the overall results out of 10 points were reported. These tests were the short versions of the TOEFL ITP listening test, but they also contained the same three parts, with six short-conversation items in the first part, and two long-and short-talk items in the second and third parts. The use of the short versions of TOEFL ITP listening tests for the immediate post-tests was due to time constraints since it was not possible to administer a full TOEFL ITP listening test in the learners' regular classes every two weeks (see the data collection procedure). 

learners’ listening comprehension. Journal of Second Language Pronunciation.

To elicit learners' perceptions of the pronunciation instruction and its effect on their listening comprehension, learners' weekly reflections, a written exit questionnaire adapted from previous research (Baralt, Gurzynski-Weiss \& Kim, 2016; Fuji, Ziegler \& Mackey, 2016), and semistructured focus group interviews were used. Each weekly reflection consisted of self-ratings and open-ended questions. The self-rating section elicited learners' opinions about seven statements using a 5-point Likert scale. The first three items focused on their increased knowledge of English pronunciation after each instruction session; the last four items investigated their perceived impact of this gained knowledge on their listening comprehension. The open-ended section consisted of five questions that further explored the learners' pronunciation knowledge and its impact on their listening comprehension (Appendix 1).

The exit questionnaire had three self-rating items and three open-ended questions to evaluate the overall impact of all seven pronunciation instruction sessions on the learners' listening comprehension. The three self-rating items explored the learners' overall perceptions of the helpfulness of the pronunciation instruction, their degree of preference towards the instruction sessions, and whether they desired to continue receiving further pronunciation instruction in future listening courses. The three open-ended questions explored the perceived impact of the pronunciation instruction on listening performance and phonology-related strategies for practicing and developing their listening comprehension (Appendix 2). The semi-structured focus group interviews were used to clarify learners' comments in the weekly reflections and the exit questionnaire, and further explored their perceptions of the pronunciation instruction and its perceived impact on listening comprehension (Appendix 2).

\subsection{Procedure}



learners' listening comprehension. Journal of Second Language Pronunciation.

Data were collected during twelve sessions of the learners' regularly scheduled classes over a fifteen-week semester (Table 1). In the first week, both the pronunciation and control groups completed a consent form, a background questionnaire, and a full TOEFL ITP pre-test. In the following weeks, the pronunciation group received seven pronunciation instruction sessions (one session per week), with each instructional session focusing on one aspect of English pronunciation, followed by a weekly reflection. Three immediate TOEFL ITP post-tests (short versions) were delivered in week 3 (after two sessions on syllables and consonants/vowels), week 7 (after three additional suprasegmental-focused sessions) and week 10 (after another two suprasegmentalfocused sessions). Participants also filled out an exit questionnaire after all seven pronunciation instruction sessions. Twenty volunteer learners from the pronunciation group (four learners per interview) participated in the focus group interviews. In the final week, they completed a full TOEFL IPT delayed post-tests. The control group did not receive any explicit pronunciation instruction but completed the same TOEFL ITP tests as did the pronunciation group. Since the control group did not receive pronunciation instruction in class, they did vocabulary tasks from the textbook while the pronunciation group carried out the pronunciation instruction sessions. To balance exposure to the L2 between two groups, the pronunciation group did the vocabulary tasks at home to dedicate time to the pronunciation sessions in class. These vocabulary tasks did not serve any purposes for the current study but were a preparation for their subsequent reading class.

Table 1

Data collection procedure

Week Pronunciation group $\quad$ Control Group

1 Consent form, background questionnaire, and full TOEFL ITP pre-test 
Dao, P., Nguyen, M. \& Nguyen, C. (2020, in press). Effect of pronunciation instruction on L2 14 learners' listening comprehension. Journal of Second Language Pronunciation.

$2 \quad$ Vocabulary tasks (at home)

Syllables session and reflection $\quad$ Vocabulary tasks in class

$3 \quad$ Vocabulary tasks (at home)

Vowels/Consonants session $\quad$ Vocabulary tasks in class

Immediate post-test 1 and reflection Immediate post-test 1

$4 \quad$ Vocabulary tasks (at home)

Word stress session and reflection $\quad$ Vocabulary tasks in class

$6 \quad$ Vocabulary tasks (at home)

Thought groups session and reflection $\quad$ Vocabulary tasks in class

$7 \quad$ Vocabulary tasks (at home)

Sentence focus session $\quad$ Vocabulary tasks in class

Immediate post-test 2 and reflection Immediate post-test 2

$9 \quad$ Vocabulary tasks (at home)

Intonation session and reflection $\quad$ Vocabulary tasks in class

$10 \quad$ Vocabulary tasks (at home)

Connected speech session Vocabulary tasks in class

Immediate post-test 3 and reflection Immediate post-test 3

11 Exit questionnaire

Semi-structured interviews

12 Delayed full TOEFL ITP Listening post-test

\subsection{Data analysis}



learners' listening comprehension. Journal of Second Language Pronunciation.

To answer the first research question that asked whether the pronunciation instruction affected the learners' listening comprehension, immediate and delayed post-test scores of TOEFL ITP listening tests of the two groups were compared using independent $t$-tests. In addition, to explore the learners' perceptions of the effect of the pronunciation knowledge gained from the pronunciation instruction on their listening comprehension, the questionnaire self-ratings were analysed (descriptive statistics). Learners' comments from the weekly reflections and interviews were analysed using the content analysis approach (Dörnyei, 2007) to supplement the self-ratings.

\section{Results}

\subsection{Pronunciation instruction and listening comprehension}

To investigate whether the pronunciation instruction affected L2 learners' listening comprehension, immediate and delayed post-test scores of listening comprehension tests were compared between the treatment and control groups, with alpha adjusted at $.013(.05 / 4)$. As shown in Table 2, there were no significant differences between the two groups after two pronunciation instruction sessions on syllables and vowels/consonants.

\section{Table 2}

Means and standard deviations of listening comprehension immediate and delayed post-test scores

\begin{tabular}{|c|c|c|c|c|c|c|c|c|}
\hline & \multirow{2}{*}{\multicolumn{2}{|c|}{$\begin{array}{c}\text { Pronunciation } \\
\text { group }\end{array}$}} & \multirow{2}{*}{\multicolumn{2}{|c|}{$\begin{array}{l}\text { Control } \\
\text { group }\end{array}$}} & \multirow[b]{3}{*}{$t$} & \multirow[b]{3}{*}{$d f$} & \multirow[b]{3}{*}{$p$} & \multirow[b]{3}{*}{$d$} \\
\hline & & & & & & & & \\
\hline & $M$ & $S D$ & $M$ & $S D$ & & & & \\
\hline Immediate post-test 1 & 3.95 & 2.04 & 3.54 & 1.46 & .96 & 70 & .343 & .23 \\
\hline Immediate post-test 2 & 4.81 & 2.45 & 3.23 & 1.77 & 3.13 & 70 & .009 & .74 \\
\hline Immediate post-test 3 & 4.03 & 2.06 & 3.17 & 1.62 & 1.95 & 70 & .049 & .46 \\
\hline
\end{tabular}


learners' listening comprehension. Journal of Second Language Pronunciation.

$\begin{array}{lllllllll}\text { Delayed TOEFL ITP Post-test } & 43.72 & 6.04 & 42.31 & 4.22 & 1.15 & 70 & .262 & .27\end{array}$

However, the pronunciation group outperformed the control group after receiving three further pronunciation sessions on word stress, thought groups and sentence focus. Specifically, the pronunciation groups' mean score increased from 3.95 on the first immediate post-test to 4.81 on the second immediate post-test whereas the control group's mean score decreased, albeit not significantly, from the first immediate post-test to the second immediate post-test. It appears that learners in the pronunciation group had one more correct answer (based on the 10-item test) on the second immediate post-test than they did on the first immediate post-test. Cohen's $d=.74$ showed a medium effect size of the difference between the two groups.

Although both groups then received two additional pronunciation sessions on intonation and connected speech, the listening comprehension scores of both groups decreased from the previous immediate post-test scores and did not differ significantly. The delayed post-tests also showed no significant differences between the two groups.

\subsection{Learners' perceptions of the impact of pronunciation instruction on listening comprehension}

To explore learners' perceptions of the impact of the pronunciation instruction on listening comprehension, learners' self-ratings (descriptive statistics), weekly reflections, and focus group interview responses were analysed.

\subsubsection{Impact of pronunciation instruction on learners' knowledge of English pronunciation}

Learners reported that pronunciation instruction helped improve their pronunciation knowledge. In Table 3, their self-ratings of knowledge about English pronunciation on a 5-point Likert scale after each pronunciation session were all high, with the lowest score of 3.7. This 
learners' listening comprehension. Journal of Second Language Pronunciation.

indicates that they understood the segmental and suprasegmental aspects of English that were taught each week, gained more metalinguistic knowledge about these aspects, and were confident to explain them to others.

Table 3

Weekly self-ratings of learners' pronunciation knowledge

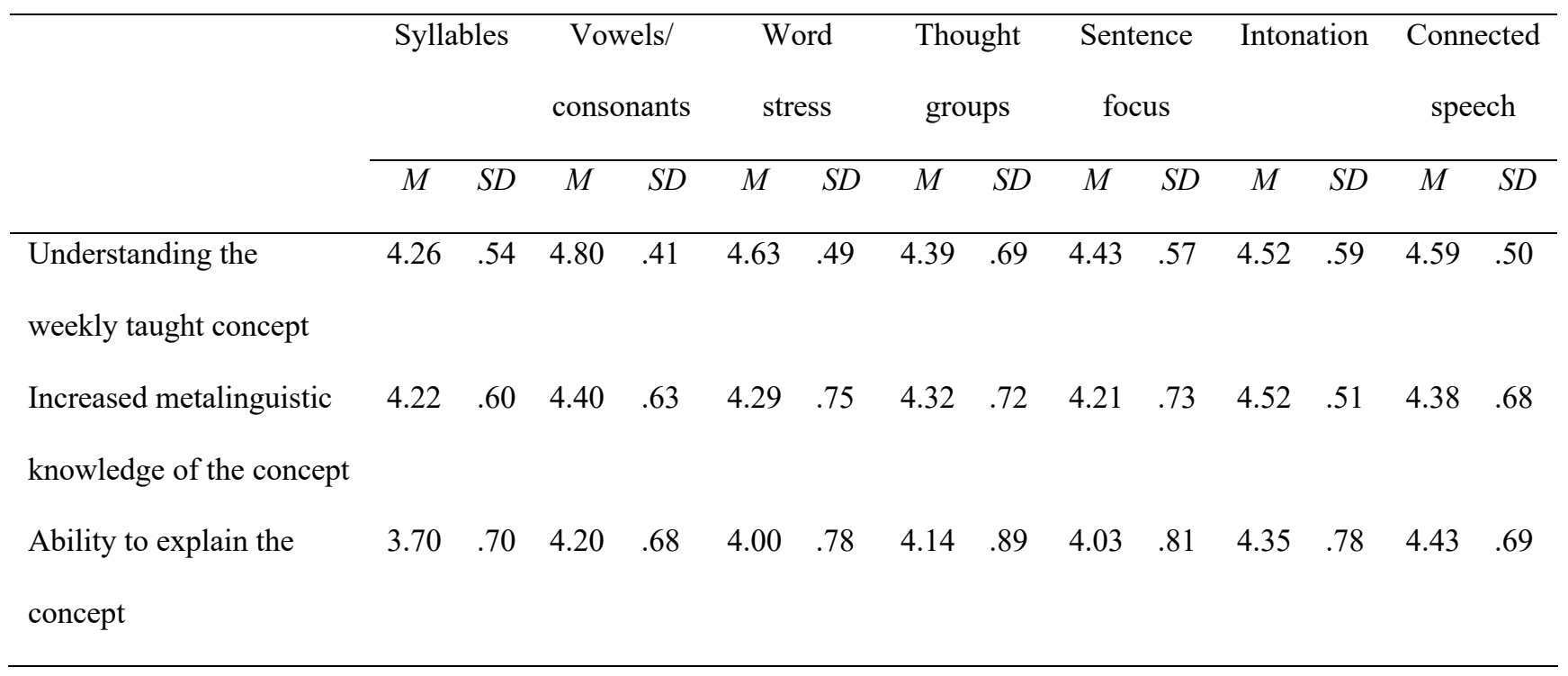

Learners' responses in the weekly reflections and interviews also revealed gains in their knowledge of English pronunciation. In the weekly reflections, when prompted to specify 'three most important things' that they learned after each pronunciation instruction session, the participants reported three main levels of impact. The most common level, cited between $58 \%$ to $74 \%$ of the time across seven sessions, was that they gained new knowledge about each weekly taught phonological aspect. Comments such as 'I learned about the differences in pronunciation between one- and two-syllable words' (Participant 1010, Session on 'Syllables'), and 'I learned how not to be confused when listening to sounds that link with each other, e.g., linking between vowel sounds and between vowel and consonant sounds' (Participant 2016, Session on 'Linking') are prevalent in 
learners' listening comprehension. Journal of Second Language Pronunciation.

their reflections. In the exit questionnaire, a learner also acknowledged her increased knowledge about English pronunciation as follows: 'I can differentiate some words that are pronounced similarly. I can speak for longer stretches with intonation and connected speech' (Participant ID 1020).

Additionally, the learners reported being able to revise and reinforce their previous knowledge of English pronunciation. An example is one learner's remark following the pronunciation session on 'Vowels': 'The session helped me to review my awareness of English vowels, especially the differences between alphabet and relative vowel sounds and how they affect pronunciation' (Participant ID 1009). Finally, several learners stated that they could adjust and correct their misunderstanding of certain aspects of English pronunciation as a result of the pronunciation instruction. This is demonstrated in comments such as 'I realised that knowing what word to emphasize in a sentence is so important - it could change the meaning of the whole sentence! This is something I did not pay attention to before' (Participant ID 1018, Session on 'Sentence stress'). In summary, the self-rating and self-report data showed that the pronunciation instruction enhanced learners' knowledge of segmental and suprasegmental aspects of English.

\subsubsection{Perceived impact of increased pronunciation knowledge on listening comprehension}

The knowledge gained from the pronunciation instruction reported above was perceived by the learners to affect their listening comprehension. They reported high ratings for the impact of the pronunciation instruction on improving listening comprehension.

\section{Table 4}

Self-ratings of the impact of phonological knowledge on listening comprehension

\begin{tabular}{|c|c|c|c|c|c|c|}
\hline \multirow[t]{2}{*}{ Syllables } & Vowels \& & Word & Thought & Sentence & Intonation & Connected \\
\hline & consonants & stress & groups & focus & & speech \\
\hline
\end{tabular}


learners' listening comprehension. Journal of Second Language Pronunciation.

\begin{tabular}{|c|c|c|c|c|c|c|c|c|c|c|c|c|c|c|}
\hline & $M$ & $S D$ & $M$ & $S D$ & $M$ & $S D$ & $M$ & $S D$ & $M$ & $S D$ & $M$ & $S D$ & $M$ & $S D$ \\
\hline Helpfulness for listening & 3.48 & .90 & 4.06 & .77 & 4.17 & .87 & 4.07 & .83 & 4.30 & .60 & 4.26 & .62 & 4.06 & .75 \\
\hline Understanding of the contribution & 3.95 & .58 & 4.27 & .70 & 4.04 & .75 & 4.11 & .80 & 4.07 & .69 & 4.26 & .62 & 4.11 & .74 \\
\hline \multicolumn{15}{|l|}{ of the phonological knowledge } \\
\hline \multicolumn{15}{|l|}{ the phonological knowledge } \\
\hline Using the phonological & 4.30 & .70 & 4.60 & .63 & 4.63 & .58 & 4.44 & .70 & 4.23 & .73 & 4.35 & .65 & 4.43 & .69 \\
\hline \multicolumn{15}{|l|}{ knowledge for developing } \\
\hline
\end{tabular}

Table 4 shows that the majority of the learners were aware of the helpfulness and contribution of the awareness of each phonological concept to the improvement of their listening comprehension and understood how to apply this knowledge in developing their listening comprehension $(\mathrm{M}>4.0)$. They also reported to use this gained pronunciation knowledge in future practice for developing listening comprehension $(\mathrm{M} \geq 4.23)$. In addition, the self-ratings of the helpfulness of knowledge gained from the pronunciation sessions corresponded to the overall selfratings of all pronunciation sessions in the exit questionnaire (Table 5). The learners highly rated the overall helpfulness of and preference for all pronunciation sessions, and unanimously indicated desire for further pronunciation instruction.

Table 5

Overall perceptions towards all pronunciation sessions

\begin{tabular}{lr}
\hline Items & $M D$ \\
\hline Helpfulness of all pronunciation sessions for listening comprehension & 4.10 \\
Overall preference towards the pronunciation instruction & .74 \\
Desire for continuity of prospective pronunciation instruction & .55 \\
\end{tabular}


learners’ listening comprehension. Journal of Second Language Pronunciation.

The weekly reflections and interview responses further supported the questionnaire data. The learners were positive that improved pronunciation skills could help enhance listening comprehension. One learner was able to pinpoint how enhanced pronunciation abilities helped her decode sounds when listening: 'If we have good pronunciation, then we can listen to the words that they [English speakers] are saying. If we can identify the words they are saying, we can understand the content' [Exit questionnaire, Participant ID 1020]. Similarly, another learner stated, 'listening and speaking are interdependent and that if we can recognize the correct way to pronounce a word...then we can understand the content of a recording...' [Focus group 2, Participant ID1037]

More importantly, most of the learners (31 out of 35) reported applying the knowledge gained from the pronunciation instruction in their out-of-class listening comprehension practice. One learner reported 'When I listen at home, I pay attention to things such as connected speech words, things that I have learnt in class that I find familiar' (Focus group 3, Participant ID1052). Likewise, another learner remarked, 'I began to notice the pronunciation features learned in class when practicing listening, and paid more attention to it and repeated the recording several times in those instances...so I could listen better I could understand better'. [Focus group 4, Participant ID 1060].

Finally, learners' comments revealed the perceived positive impact of the pronunciation instruction on their pronunciation and listening comprehension. All learners reported that the phonological discrimination activities increased their abilities to perceive the aspects of phonology being taught when they occur in natural speech. At the same time, the production-oriented activities helped them practice their pronunciation and reinforce the phonological features under practice, as commented by Participant ID 1004: 'The combination of the activities in the pronunciation instruction sessions helped me practice my pronunciation skills. This makes me realise how these 
learners' listening comprehension. Journal of Second Language Pronunciation.

two [listening comprehension and pronunciation] are strongly connected' [Focus group 3, Participant ID 1004].

However, a small group of four interviewed learners stated that pronunciation knowledge did not play a role in developing their listening comprehension. One learner said in the focus group interview, 'In order to be good at listening comprehension you need to listen a lot...I don't think there is connection with pronunciation' [Participant ID 1020]. However, this learner still acknowledged the relationship between listening comprehension and pronunciation knowledge. Her reasons were that she was more convinced that listening abilities would aid pronunciation skills, rather than vice versa: 'I think if we listen a lot then our pronunciation will be better... and if our pronunciation is better we can speak better...actually I think it should go in that direction [good listening skill helps develop pronunciation skill] ...but not the other way around [phonological awareness does not help develop listening comprehension], it's not so effective'. It should be noted that this learner was one of the more advanced learners whose English proficiency was considerably higher than the rest of the group. The other three learners who did not see the benefits of pronunciation instruction were low proficiency learners who struggled to complete course assignments. These learners explained that they did not find the pronunciation sessions very helpful as they were not accustomed to listening to English recordings which they claimed to be 'too fast' for them.

\section{Discussion}

\subsection{Impact of pronunciation instruction on listening comprehension}

The current study investigated whether pronunciation instruction affects learners' listening comprehension and the role of knowledge gained from the pronunciation instruction in the development of listening comprehension. The findings showed that the first two instruction sessions 
learners' listening comprehension. Journal of Second Language Pronunciation.

on consonants, vowels and syllables did not result in significant differences in the learners' immediate TOEFL ITP listening comprehension post-test scores. However, the three subsequent instruction sessions on suprasegmental aspects such as word stress, thought groups and sentence focus significantly impacted the pronunciation group's immediate post-test scores as compared to the control group. These results showed some modest evidence of the positive impact of pronunciation instruction on the learners' listening comprehension performance, suggesting that explicit pronunciation could aid in facilitating listening comprehension (Kissling, 2018).

However, this modest positive impact disappeared subsequently since the listening comprehension scores of the pronunciation and control groups were not significantly different following the additional instruction sessions on intonation and connected speech. Also, there were no statistically significant differences between the two groups on the delayed post-tests despite a slight improvement from their pre-test scores $(M=41.76, S D=5.76)$ to post-test scores $(M=43.72$, $S D=6.04)$. On the one hand, these results could suggest that learners' development of listening comprehension was dynamic, non-linear and often fluctuated during the process of development (see Larsen-Freeman, 2012; Larsen-Freeman \& Cameron, 2008). On the other hand, they indicated that the pronunciation instruction had very limited impact on learners' overall listening comprehension. One possible explanation is that the seven pronunciation instruction sessions might not be sufficient for significant differences to be detected subsequently in the delayed post-tests; similar but more longitudinal instruction of pronunciation is, therefore, required. Alternatively, it could be because measures such as TOEFL ITP listening tests, despite assessing multiple processes of listening comprehension, were not able to detect the instructional effects of the pronunciation sessions. That is, the pronunciation instruction may have increased the learners' bottom-up sound decoding skills (see Kissling, 2018) but this increase might not be sufficient to result in improved 
learners’ listening comprehension. Journal of Second Language Pronunciation.

overall listening comprehension skills, which includes both bottom-up (e.g. sound decoding) and top-down listening processes (e.g. schemata activation, information retention or identification of functions of speech events) as targeted in TOEFL ITP listening tests. Other measures that target specific bottom-up listening comprehension processes such as tailor-made tests in Kissling's (2018) study may thus be more appropriate.

\subsection{Learners' perceptions of how pronunciation instruction affects listening comprehension}

Despite the lack of significantly improved test scores, qualitative data collected from the learners' weekly reflections and interviews show that the pronunciation instruction increased their knowledge of English pronunciation, which they reported to be helpful for listening comprehension. These findings suggest that an increase in pronunciation knowledge was felt to be connected with improved listening comprehension (Brown \& Lee, 2015; Reed \& Michaud, 2011). Previous research on pronunciation instruction has tended to focus largely on developing learners' phonological knowledge and skills through pronunciation instruction (Derwing \& Munro, 2015; Kennedy \& Trofimovich, 2010). This study suggests that pronunciation instruction could help learners enhance their pronunciation knowledge (Derwing, 2017) and thus possibly improve their listening comprehension (Kissling, 2015, 2018).

Additionally, the learners' reported learning, ranging from gaining new knowledge about the phonological aspects being taught, to reinforcing and revising previously learned knowledge, strongly correspond with what Schmidt (1990) and van Lier (1998) conceptualized as more advanced stages of language awareness and consciousness, which advances from 'noticing' (ability to recognize and pay attention to language events or phenomena), to 'understanding' (ability to form rules and patterns based on observed events). These deeper levels of understanding that resulted from the learners' participation in the pronunciation instruction sessions further reinforce the benefit 
learners' listening comprehension. Journal of Second Language Pronunciation.

of explicit pronunciation instruction and could potentially explain why these learners were able to use this greater knowledge for developing listening comprehension. These self-report results, however, should be interpreted with caution. Although learners claimed to gain more pronunciation knowledge, this may not always translate into improved listening comprehension scores, as seen in this paper. Further research is, therefore, needed to confirm this interpretation.

In their reflective responses, the learners also stated they paid greater attention to phonological aspects of English while practicing listening comprehension, which reportedly helped them listen better. They even claimed to continue using this pronunciation knowledge for their further listening practice outside of class and to form phonological rules to improve their listening comprehension. These results demonstrate that the learners used the knowledge gained from the pronunciation sessions as a strategy for practicing listening comprehension. Thus, this study advocates that pronunciation instruction may be used as a learning strategy for improving listening comprehension and it could be used in combination with instructional sessions on top-down listening processes (i.e. listening for main ideas/details; metacognitive strategies) (Graham \& Macaro, 2008; Ngo, 2015; Vandergrift \& Baker, 2015).

\subsection{Pedagogical benefits of pronunciation instruction for listening comprehension}

In line with the results from weekly reflections, the learners reported in the exit questionnaire that the pronunciation instruction impacted their listening comprehension positively. Thus, they were favourable toward the pronunciation instruction sessions and desired to receive further instruction on this area to develop their listening comprehension. These results suggest that the fourstage pedagogical procedure of teaching pronunciation in this study could be one of the instructional techniques that L2 teachers could use for promoting learners' pronunciation knowledge with a view to developing listening comprehension. In addition, given the lack of emphasis on pronunciation 
learners' listening comprehension. Journal of Second Language Pronunciation.

teaching in many language classrooms across contexts (see Henderson et al., 2012; Foote, Holtby, \& Derwing, 2011; Darcy, Ewert, \& Lidster, 2012), this concise four-stage framework that incorporates both perception- and production-based activities could be a useful pedagogical reference for L2 teachers wishing to integrate pronunciation teaching into their listening comprehension curricula.

However, it should be noted that pronunciation instruction did not work for all learners in the present study; a few of them did not perceive the pronunciation sessions as useful for developing listening comprehension. These learners seemed to consider pronunciation instruction as mainly for speaking classes. This may be due to the fact that in some L2 learning and teaching contexts, skills such as listening comprehension, pronunciation, reading and writing are being taught separately (Brown \& Lee, 2015; Richards \& Burns, 2012). However, given that all skills are developed in connection with each other (Brown \& Lee, 2015; Brown, 2011; Hinkel, 2006), current research has provided support for integrated-skills teaching. Thus, it is important to emphasize to the learners at the beginning and throughout the delivery of pronunciation instruction sessions the potential link between pronunciation and listening comprehension as well as how these skills should be acquired and practiced.

Another factor to consider is the impact of pronunciation instruction as a bottom-up listening strategy may vary depending on learners' proficiency levels. In the present study, a small group of learners who had either considerably higher or lower proficiency than the rest of the group did not benefit from the pronunciation sessions on their listening comprehension. This finding partly corroborates with Vandergrift and Baker (2015), who found that bottom-up processing skills are more useful for low proficiency learners as these strategies tend to be utilized more by learners in the early stages of language acquisition. What our study adds to this line of argument is that very high or very low-proficiency learners might not benefit much from pronunciation instruction 
learners' listening comprehension. Journal of Second Language Pronunciation.

targeting at improving listening comprehension. This kind of instruction, therefore, might be more appropriately implemented with intermediate level learners rather than very high or very lowproficiency learners.

\section{Limitations}

The current study has limitations that need to be taken into consideration when interpreting the results. First, since the long-term impact of the pronunciation instruction on the learners' listening comprehension was not detected in the last immediate and delayed post-tests, future research may need to carry out pronunciation instruction over a longer period in order to potentially detect the impact of instruction. Second, the current study focused exclusively on providing learners with pronunciation instruction to promote their pronunciation knowledge and relied on the assumption that learners would use this knowledge to decode spoken language for comprehension (i.e. bottom-up listening processes). Thus, it did not take into consideration training that focuses on top-down listening processes. It would be more informative if future research combined instruction on both bottom-up and top-down listening processes to examine how they together impact learners' listening comprehension (see Graham \& Macaro, 2008; Yeldham, 2016).

\section{Conclusion}

This study examined whether pronunciation instruction impacted L2 learners' listening comprehension and how the learners perceived the role of knowledge about English pronunciation on their development of listening comprehension. The results provided limited evidence that pronunciation knowledge gained from the pronunciation instruction benefitted the learners' subsequent listening comprehension performance. The learners, however, reported that the gained knowledge helped them in their practice of developing listening comprehension and using it for further practice of listening comprehension. These results suggest some benefits of pronunciation 

learners’ listening comprehension. Journal of Second Language Pronunciation.

instruction to the learners' perceptions of listening comprehension improvement. Pronunciation instruction, therefore, could be potentially seen as a pedagogical strategy to be incorporated into L2 listening comprehension curricula to enhance L2 learners' listening comprehension.

\section{Acknowledgements}

Funding for this project was obtained from the TOEFL English-language Researcher/Practitioner Grant, awarded by ETS. A special thanks to ETS and Yuan Wang, Ikkyu Choi, and Ching-Ni Hsieh from ETS team for the provision and the marking of TOEFL ITP tests and their assistance throughout the project. We also would like to thank two anonymous reviewers and the editor, John M. Levis, for their insightful feedback and editing work. We are also grateful to the students of Hue University of Foreign Languages, Vietnam, for their participation and support in this project. All remaining errors are ours. 
learners’ listening comprehension. Journal of Second Language Pronunciation.

Author 1

\section{Phung Dao}

Lecturer in Department of Languages, Information and Communications

Manchester Metropolitan University

Geoffrey Manton, All Saints campus

Manchester, England, M15 6LL

Email: p.dao@mmu.ac.uk

Author 2

\section{Mai Xuan Nhat Chi Nguyen}

Lecturer in Department of Languages, Information and Communications

Manchester Metropolitan University

Geoffrey Manton, All Saints campus

Manchester, England, M15 6LL

Email: m.nguyen@mmu.ac.uk

Author 3

\section{Ngoc Bao Chau Nguyen}

Lecturer in Department of English

Hue University of Foreign Languages

57 Nguyen Khoa Chiem, An Cuu Ward

Hue City, Vietnam

Email: chaunguyen@hueuni.edu.vn 
learners’ listening comprehension. Journal of Second Language Pronunciation.

\section{References}

Baralt, M., Gurzynski-Weiss, L., \& Kim, Y. (2016). The effects of task complexity and classroom environment on learners' engagement with the language. In M. Sato \& S. Ballinger (Eds.), Peer interaction and second language learning: Pedagogical potential and research agenda, (pp. 209 -239). Amsterdam: John Benjamins.

Brown, H., \& Lee, H. (2015). Teaching by principles: An interactive approach to language pedagogy (Fourth ed.). White Plains, NY: Pearson Education.

Brown, S. (2011). Listening myths. Ann Arbor: University of Michigan Press.

Celce-Murcia, M., Brinton, D. M., \& Goodwin, J. M. (2010). Teaching pronunciation: A course book and reference guide. Cambridge: Cambridge University Press.

Darcy, I., Ewert, D., \& Lidster, R. (2012). Bringing pronunciation instruction back into the classroom: An ESL teacher's pronunciation “toolbox”. In J. Levis \& K. LeVelle (Eds),

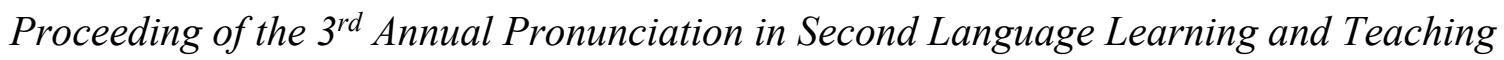
Conference (pp. 93-108). Ames, IA: Iowa State University.

Derwing, T. M. (2017). The role of phonological awareness in language learning. In P. Garett \& J. M. Cots, The Routledge Handbook of Language Awareness (pp. 339-353). New York: Routledge.

Derwing, T. M., Diepenbroek, L. G., \& Foote, J. A. (2013). How well do general-skills ESL textbooks address pronunciation? TESL Canada Journal, 30(1), 22-44.

Derwing, T. M., \& Munro, M. J. (2015). Pronunciation fundamentals: Evidence-based perspectives for L2 teaching and research. Amsterdam: John Benjamins. 
Dao, P., Nguyen, M. \& Nguyen, C. (2020, in press). Effect of pronunciation instruction on L2

learners' listening comprehension. Journal of Second Language Pronunciation.

Derwing, T. M., Munro, M. J., Foote, J. A., Waugh, E., \& Fleming, J. (2014). Opening the window on comprehensible pronunciation after 19 years: A workplace training study. Language Learning, 64(3), 526-548.

Dörnyei, Z. (2007). Research methods in applied linguistics. New York: Oxford University Press.

Field, J. (2009). Listening in the language classroom (Cambridge language teaching library). Cambridge: Cambridge University Press.

Flege, J. E. (1995). Second language speech learning: Theory, findings, and problems. In W. Strange (Ed.), Speech perception and linguistic experience: Issues in cross-language research (pp. 233-277). Timonium, MD: York Press.

Foote, J., Holtby, A., \& Derwing, T. (2011). Survey of the teaching of pronunciation in adult ESL program in Canada, 2010. TESL Canada Journal, 29, 1-22.

Fujii, A., Ziegler, N., \& Mackey, A. (2016). Peer interaction and metacognitive instruction in the EFL classroom. In Sato, M. \& Ballinger, S. (Eds.) Peer interaction and second language learning: Pedagogical potential and research agenda, (p.63 -90). Amsterdam: John Benjamins.

Gilbert, J. B. (2012). Clear Speech teacher's resource and assessment book: Pronunciation and listening comprehension in North American English. Cambridge: Cambridge University Press.

Gilbert, J. B. (2019). An informal account of how I learned about English rhythm. TESOL Journal. Published online Jan 2019. doi: 10.1002/tesj.441

Goh, C. C. (2000). A cognitive perspective on language learners' listening comprehension problems. System, 28(1), 55-75. 
learners' listening comprehension. Journal of Second Language Pronunciation.

Goh, C., \& Taib, Y. (2006). Metacognitive instruction in listening for young learners. ELT Journal, 60(3), 222-232. doi:10.1093/elt/cc1002

Graham, S. (2006). Listening comprehension: The learners' perspective. System, 34(2), 165-182.

Graham, S., \& Macaro, E. (2008). Strategy instruction in listening for lower-intermediate learners of French. Language Learning, 58(4), 747-783.

Hasan, A. S. (2000). Learners' perceptions of listening comprehension problems. Language Culture and Curriculum, 13(2), 137-153.

Henderson, A., \& Frost, D., Tergujeff, E., Kautzch, A., Murphy, D., Kirkova-Naskova, A., WaniekKlimczak, E., Kevey, D, Cunningham, C., \& Curnick, L. (2012). The English pronunciation teaching in Europe survey: Selected results. Research in Language, 10, 5 - 27.

Hinkel, E. (2006). Current perspectives on teaching the four skills. TESOL Quarterly, 40, 109-131.

Kennedy, S., \& Trofimovich, P. (2010). Language awareness and second language pronunciation: A classroom study. Language Awareness, 19, 171-185.

Kissling, E. (2013). Teaching pronunciation: Is explicit phonetics instruction beneficial for FL learners? The Modern Language Journal, 97(3), 720-744.

Kissling, E. (2015). Phonetics instruction improves learners' perception of L2 sounds. Language Teaching Research, 19(3), 254-275.

Kissling, E. M. (2018). Pronunciation Instruction Can Improve L2 Learners’ Bottom-Up Processing for Listening. The Modern Language Journal, 102(4), 653-675.

Larsen-Freeman, D. (2012). Complex, dynamic systems: A new transdisciplinary theme for applied linguistics? Language Teaching, 45, 202-214

Larsen-Freeman, D., \& Cameron, L. (2008). Research methodology on language development from a complex systems perspective. Modern Language Journal, 92, 200-213. 
learners' listening comprehension. Journal of Second Language Pronunciation.

Merdinger, P. \& Barton, L. (2009). NorthStar: Listening and speaking Level 1. New York: Pearson. Morley, J. (1991). The pronunciation component in teaching English to speakers of other languages. TESOL Quarterly, 25(3), 481-520. http://dx.doi.org/10.2307/3586981

Ngo, N. T. H. (2015). Some insights into listening strategies of learners of English as a foreign language in Vietnam. Language, Culture and Curriculum, 28(3), 311-326.

Reed, M. \& Michaud, C. (2011). An integrated approach to pronunciation: Listening comprehension and intelligibility in theory and practice. In. J. Levis \& K. LeVelle (Eds.). Proceedings of the 2nd Pronunciation in Second Language Learning and Teaching Conference, Sept. 2010. (pp. 95-104), Ames, IA: Iowa State University.

Renandya, W. A., \& Farrell, T. S. C. (2011). 'Teacher, the tape is too fast!' Extensive listening in ELT. ELT Journal, 65(1), 52-59. doi:10.1093/elt/ccq015

Richards, J. C., \& Burns, A. (Eds.). (2012). The Cambridge guide to pedagogy and practice in second language teaching. Cambridge University Press.

Schmidt, R. W. (1990). The role of consciousness in second language learning. Applied linguistics, $11,129-158$.

Takeuchi, O. (2003). What can we learn from good foreign language learners? A qualitative study in the Japanese foreign language context. System, 31(3), 385-392.

Vandergrift, L., \& Baker, S. (2015). Learner variables in second language listening comprehension: An exploratory path analysis. Language Learning, 65(2), 390-416.

Vandergrift, L., \& Goh, C. C. (2012). Teaching and learning second language listening: Metacognition in action. Routledge.

Van Lier, L. (1998). The relationship between consciousness, interaction, and language learning. Language Awareness, 7, 128-140. 
learners' listening comprehension. Journal of Second Language Pronunciation.

Yeldham, M. (2016). Second language listening instruction: Comparing a strategies-based approach with an interactive, strategies/bottom-up skills approach. TESOL Quarterly, 50, 394-420.

Yeldham, M., \& Gruba, P. (2014). Toward an instructional approach to developing interactive second language listening. Language Teaching Research, 18(1), 33-53. 
learners’ listening comprehension. Journal of Second Language Pronunciation.

\section{Appendices}

\subsection{Appendix 1: A sample plan of a pronunciation session}

\section{Topic: THOUGHT GROUPS}

Session aims:

1- To introduce students to the features of thought groups/intonation units in natural spoken English

2- To help students to use knowledge of thought groups to improve their listening skills (also speaking skills)

Session objectives: By the end of the session students will be able to:

1- Identify thought groups when listening to naturally spoken English

2- Chunk words into thought groups/intonation units in guided and communicative speaking practice

Session material sources: (Baker \& Goldstein, 2008; Gilbert, 2002; Hancock, 2003)

\section{Procedure}

A. Description and analysis: Introducing thought groups

1. Example:

Listen to the teacher saying either sentence (a) or (b) and choose the correct answer to the given question.

a. The teacher said, 'The student is lazy'.

b. 'The teacher', said the student, 'is lazy'. Question: Who is lazy?

2. Analysis: How did you identify whether the teacher said (a) or (b)?

3. Thought groups:

a. What is a thought group?

- a group of words that belong together and reflect how people organise their thoughts

- can be a short sentence or part of a longer sentence.

b. How do thought groups help with listening comprehension?

\section{Rules for Identifying thought groups}

1 Listen to these sentences and notice how pauses are used between the thought groups.

1. I'd like six oranges, and two wedges of cheese.

2. When you get there, call me, and I'll come get you.

3. "Let's go for a walk," I said. But she replied, "I'm busy."

\section{Thought Group Rule 1}

There is often a pause at the end of a thought group to signal that the thought group is finished.

\section{Phone numbers}

\section{Thought Group Rule 2}

There is often a fall in pitch at the end of a thought group to signal that the thought group is finished. 
learners' listening comprehension. Journal of Second Language Pronunciation.

\section{B. Listening discrimination: Listening for thought groups}

1. As you listen, mark a slash (/) where you hear pauses. (Hint: there are six pauses)

\section{Introducing Steve and Rosemary}

Steve this is my friend Rosemary she's a student at Wilson Middle School Mary this is Steve he's a student too she's in my math class.

2. 
learners’ listening comprehension. Journal of Second Language Pronunciation.

\section{N Pair work: Identifying thought groups}

Student A: Say either sentence $\mathbf{a}$ or $\mathbf{b}$. Then ask the question underneath the two sentences.

Student B: Respond with the appropriate answer on the right.

\section{Example}

Student A: "Do you want soup or salad?"

"How many things were you offered?"

Student B: "Two."

1. a. Do you want a Super Salad?

b. Do you want a soup or salad?

One.

Question: How many things were you offered?

2. a. Jane said, "Is that Mister Fogg?"

b. Jane said, "Is that mist or fog?"

Question: What was Jane asking about?

3. a. He sold his house, boat, and car.

b. He sold his houseboat and car.

Question: How many things did he sell?

4. a. She likes pie and apples.

b. She likes pineapples.

Question: What kind of fruit does she like?

5. a. We used wooden matches to start the fire.

b. We used wood and matches to start the fire. Question: How many things did they use?

Two.

A person.

The weather.

Three.

Two.

Apples.

Pineapples.

One.

Two.

6. a. She collects golden coins.

One.

b. She collects gold and coins.

Two.

Question: How many things did she collect?

7. a. When the water boils rapidly, put the spaghetti in the pot.

b. When the water boils, rapidly put the spaghetti in the pot.

When the water boils rapidly.

When the water Question: When should you put the spaghetti boils. in the pot?

\section{Controlled practice}


learners’ listening comprehension. Journal of Second Language Pronunciation.

1 Read the following dialogue, and make a slash where you think each thought group ends. Then underline the focus word in each thought group.

2 Practice the dialogue with a partner. Remember to use pauses and pitch to make the thought groups clear.

\section{Coffee Shop Confusion}

(The customer doesn't hear very well, and the server is impatient.)

Customer: What can I have to start with?

Server: Soup or salad.

Customer: What's Super Salad?

Server: What do you mean, "Super Salad"?

Customer: Didn't you say you have a Super Salad?

Server: No, we don't have anything like that. Just plain green salad. Or you can start with tomato soup.

Customer: Oh, OK. Well, what do you have for dessert?

Server: We have ice cream, pie, and apples.

Customer: I don't like pineapples very much.

Server: Are you making jokes or what? We have ice cream, pie, and apples.

Customer: OK, OK. Just give me the soup and a piece of apple pie.

Server: Sorry, the only pie we have is berry.

Customer: Very what?

Server: Excuse me?

Customer: You said the pie was very something. Very good?

Server: I said the pie was berry - blackberry! And if you will wait just a minute, I'm going to get another server for you.

\section{Communicative practice}

Information gap task: Each student of a pair is given three pictures from a set of 6 pictures describing a complete story (e.g., job search stories)

First, each student takes turns to describe their pictures (monologe). Then, they converse to create a complete story using the six given picturese (dialogue). Note: The teacher should stress on asking students to apply the thougth groups rules in this communicative teaching pactice. 
learners’ listening comprehension. Journal of Second Language Pronunciation.

\subsection{Appendix 2: Weekly reflection}

\begin{tabular}{|c|c|c|c|c|c|}
\hline \multirow{2}{*}{$\begin{array}{l}\text { Self-rating } \\
\text { 1. Through the pronunciation session today, I understood the } \\
\text { concept being taught. }\end{array}$} & \multicolumn{3}{|c|}{ Strongly agree } & \multicolumn{2}{|c|}{ Strongly disagree } \\
\hline & 5 & 4 & 3 & 2 & 1 \\
\hline $\begin{array}{l}\text { 2. Through the pronunciation session today, I gained more } \\
\text { metalinguistic knowledge of the taught concept. }\end{array}$ & 5 & 4 & 3 & 2 & 1 \\
\hline $\begin{array}{l}\text { 3. After the pronunciation, I am able to explain the concept to } \\
\text { others }\end{array}$ & 5 & 4 & 3 & 2 & 1 \\
\hline $\begin{array}{l}\text { 4. The gained phonological knowledge is helpful for listening } \\
\text { comprehension }\end{array}$ & 5 & 4 & 3 & 2 & 1 \\
\hline $\begin{array}{l}\text { 5. I understand how the concept contributes to improve listening } \\
\text { comprehension }\end{array}$ & 5 & 4 & 3 & 2 & 1 \\
\hline $\begin{array}{l}\text { 6. I understand how to use the concept to improve listening } \\
\text { comprehension }\end{array}$ & 5 & 4 & 3 & 2 & 1 \\
\hline $\begin{array}{l}\text { 7. I will use what is learned for future listening comprehension } \\
\text { practice }\end{array}$ & 5 & 4 & 3 & 2 & 1 \\
\hline Comments: Open-ended questions & \multicolumn{5}{|c|}{ Answers } \\
\hline $\begin{array}{l}\text { 1. What were THREE most important things that you learned } \\
\text { from the phonological pronunciation session today? }\end{array}$ & & & & & \\
\hline $\begin{array}{l}\text { 2. Do you think that the phonological knowledge you gained } \\
\text { today will help you with your listening comprehension? If yes/no, } \\
\text { why or why not? }\end{array}$ & & & & & \\
\hline $\begin{array}{l}\text { 3. Will you be able to use these things learnt today? If yes/no, } \\
\text { why or why not? }\end{array}$ & & & & & \\
\hline $\begin{array}{l}\text { 4. What were the effective aspects of the pronunciation session } \\
\text { today? }\end{array}$ & & & & & \\
\hline $\begin{array}{l}\text { 5. Were there any aspects of the pronunciation session today that } \\
\text { should be improved? }\end{array}$ & & & & & \\
\hline
\end{tabular}


learners’ listening comprehension. Journal of Second Language Pronunciation.

\subsection{Appendix 3: Exit questionnaire}

1. Overall, were the pronunciation sessions throughout the course helpful for improving listening comprehension

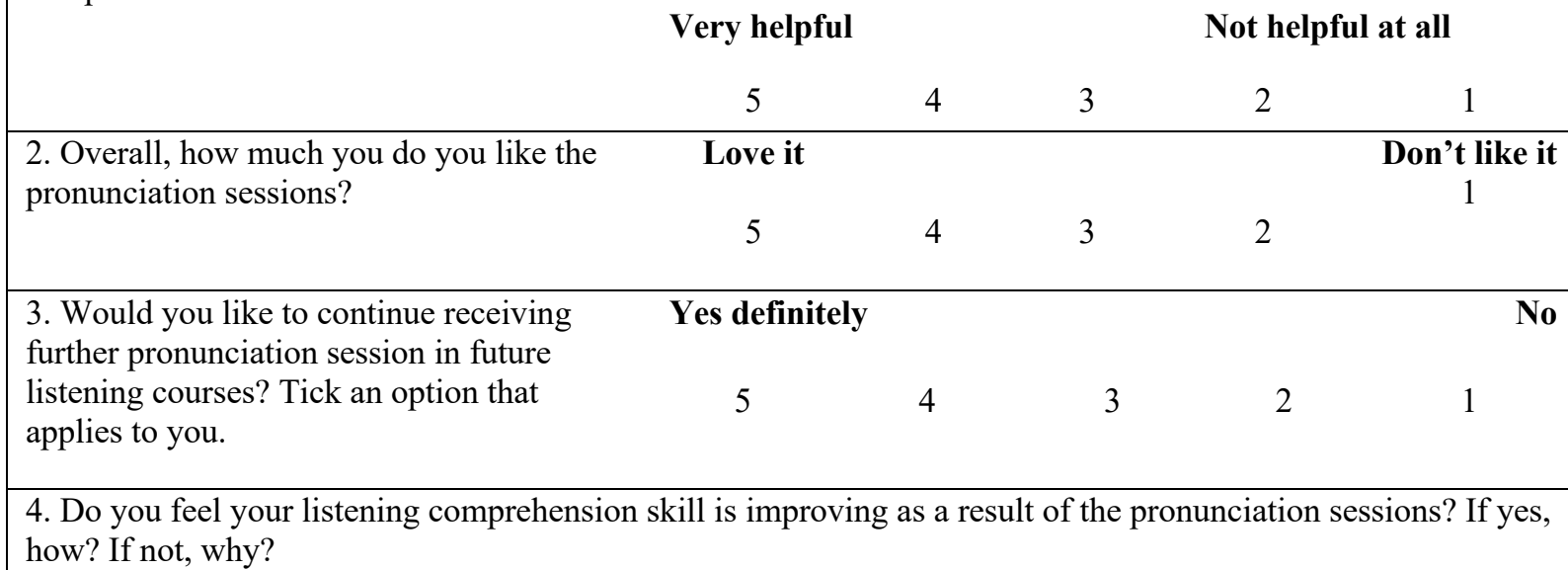

5. Did the way you practice your listening comprehension change as the pronunciation sessions went on? If yes, how? If not, why?

6. Is there anything else that you would like to say about the pronunciation sessions? 
learners’ listening comprehension. Journal of Second Language Pronunciation.

\subsection{Appendix 4: Focus group interview: Prompt questions}

1. In general, what do you think about the overall effectiveness of all pronunciation sessions on listening comprehension?

2. Did the way you practice listening comprehension change as the pronunciation sessions went on?

3. To what extent do you think that you could use what you were learning from each pronunciation session to improve your listening comprehension in general?

4. Did you feel your listening comprehension is improving as a result of the phonological pronunciation sessions? If so, how? If not, why?

5. What are the aspects of the pronunciation sessions that you have found difficult to apply to your learning?

6. What difficulties did you encounter when participating in the pronunciation sessions?

7. What aspects of the pronunciation sessions did not work well for you?

8. Do you have any comments, thoughts, and suggestions about any aspects of the pronunciation sessions? 